\title{
アイリングモデルを利用した木 LIFE PREDICTION OF THE NAILED 造住宅における鉄釘の寿命予測 JOINTS IN WOODEN HOUSES BY USING THE EYRING MODEL
}

石山央樹 — * $* 1$

中野一郎 - $* 3$

腰原幹雄 — $* 2$

関真理子 $-* 4$

キーワード :

木構造，釘接合，寿命予測，アイリングモデル

Keywords:

Wooden structure, Nail connection, Life prediction, Eyring model

\section{Hiroki ISHIYAMA $-* 1$ \\ Ichiro NAKANO $-* 3$}

Mikio KOSHIHARA - $* 2$
Mariko SEKI $* 4$

The life of the nailed joints that are used at shear walls of wooden houses was predicted by using the eyring model. In this study, the stress factors for the eyring model were the temperature of surroundings and equilibrium moisture content (EMC) of the wood in which nails were driven. And the constants of the eyring model were decided by accelerated test. The temperature and the relative humidity inside of the walls of wooden houses were measured, and the EMC of the wood were calculated.

By application of the eyring model, it was calculated that the life of the nails without surface treatment were about 230-370 years in the walls of wooden houses.
1. はじめに

木造住宅の寿命は 1980 年代前半には 30 年程度であったものが 2000 年代前半には 50 年程度になったと言われている ${ }^{1)}$ が、これは 物理的な寿命に関わらず除却されたものを含む統計であり、材料・ 工法の選択や維持管理が良い場合にはさらに耐用年数が伸びるとも 言われている2)。

近年の木造住宅では、面材耐力壁の釷やビス、柱頭柱脚金物など、 構造耐力要素としての金属接合具の使用が多くなってきており、金 属接合具の耐久性が建物の耐久性に及ぼす影響が相対的に高くなっ ていると考えられる。しかしながら、これら構造金物、特に面材耐 力壁の釷について寿命予測を行った例は殆どない。

筆者らは、高分子材料の寿命予測の分野でよく用いられるアイリ ングモデルを用い、促進実験と建物躯体内部の温湿度計測の結果を 適用することにより、面材耐力壁における釘の寿命予測を試みた。 以下に寿命予測方法とその結果について述べる。

\section{2. 寿命予測の概要}

高分子材料の寿命予測では、温度を加速因子としたアレニウスモ

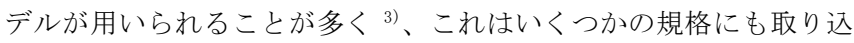
まれている例えば 4)。さらに、温度以外のストレス因子も考慮したア イリングモデルも用いられている。

木造住宅の躯体内部、特に木材に打ち込まれた鉄釘の劣化因子の 主なものとしては、含水率および酢酸が挙げられる。含水率が高く なると木材の導電率が上昇する。これは鉄釘にとって腐食電流が流 れやすくなる、すなわち腐食速度が増加することを意味する。また、
木材は温度と湿度の影響を受け、酢酸を発生する。すなわち、木材 のヘミセルロースのアセチル基が加水分解を受け、酢酸となって遊 離する ${ }^{5)}$ 。酸性環境下では鉄の腐食速度は増加する ${ }^{6)}$ 。

本研究では、高温高湿環境による釷の促進発錆実験と建物躯体内 部の温湿度計測を行い、その結果にアイリングモデルを適用するこ とにより、合板耐力壁における釘の寿命予測を試みる。本研究の概 要を図 1 に示し、以下に概要を述べる。なお、本研究では木材内の 釘を対象とするため、ストレス因子は温度および平衡含水率（EMC） とした。また、釷の腐食の程度は釷の重量で表すこととする。

(1) 木材に釘を打ち込んだ試験体をいくつかの温湿度条件に暴 露し、当該条件での木材中の釘の経時変化データを得る。

(2) 釷劣化時の構造性能実験を行い、初期構造性能を維持できな くなる釘の限界残存重量Wを設定する。

(3) (1)、(2)より、各温湿度条件における寿命 Ln を算定する。

(4) 各温度、EMC および Ln をアイリングモデルに適用し、回帰分 析によって諸定数を算出する。

(5) 木造住宅の各部位の温湿度データおよびその温湿度での EMC を(4)で得られた式に適用し、その条件下での寿命を算定する。

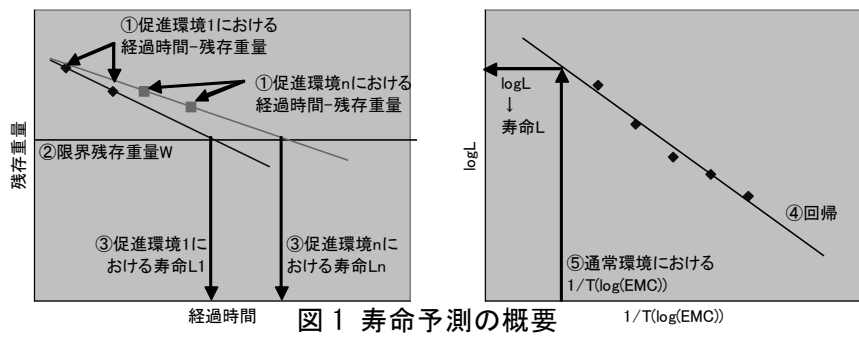

住友林業(侏筑波研究所 主任研究員 · 博士 (工学)

( ₹ 300-2646 つくば市緑ヶ原 3-2)

東京大学生産技術研究所 准教授・博士 (工学)

住友林業(株筑波研究所 主任研究員

住友林業(侏)筑波研究所 研究員・工修
Senior Researcher, Sumitomo Forestry Co., Ltd., Tsukuba Research Institute, Dr. Eng.

2 Associate Prof., Institute of Industrial Science, The Univ. of Tokyo, Dr. Eng. Senior Researcher, Sumitomo Forestry Co., Ltd., Tsukuba Research Institute Researcher, Sumitomo Forestry Co., Ltd., Tsukuba Research Institute, M. Eng. 


\section{3. アレニウス則とアイリングモデル}

主に高分子材料の寿命予測では、温度を加速因子としたアレニウ ス則を用いた加速試験が行われることが多い。アレニウス則は温度 をパラメータとして化学反応速度を表したものであり、下式で表さ れる。

$$
K=A \times \exp \left(\frac{-E_{a}}{R \times T}\right)
$$

ただし、

$K$ : 反応速度定数、 $A$ : 定数、 $E a$ : 活性化エネルギー、 $R$ : ボルツマ ン定数、 $T:$ 絶対温度

ここで、ある状態に至るまでの時間（ここでは寿命）を $L$ とする と、 $L$ と $K$ は逆数の関係であるので、

$$
L=A^{\prime} \times \exp \left(\frac{E_{a}}{R \times T}\right)
$$

ただし、 $L$ ：ある状態に至るまでの時間、 $A^{\prime}$ : 定数

アイリングモデルはアレニウス則を温度以外のストレス因子、例 えば湿度や機械的応力、電圧などもパラメータとして化学反応速度 を表したものであり、下式で表される。

$$
K=A \times \exp \left(\frac{-E_{a}}{R \times T}\right) \times(S)^{n}
$$

ただし、 $K$ : 反応速度定数、 $A 、 n:$ 定数、 $E a$ : 活性化エネルギー、 $R$ : ボルツマン定数、 $T$ : 絶対温度、 $S$ : 温度以外のストレス因子 上と同様にある状態に至るまでの時間を $L$ として、

$$
L=A^{\prime} \times \exp \left(\frac{E_{a}}{R \times T}\right) \times(S)^{-n}
$$

と表される。ここで両辺の対数をとり、 $\log A=a 、 E a / R=k$ とおくと、

$$
\log L=a+k \times \frac{1}{T}-n \times \log (S)
$$

すなわち、 $\log L$ は $1 / T$ と $\log (S)$ の一次結合で表される。パラメー 夕 $T$ と $S$ の組合せ 3 水準以上について促進実験を行えば、重回帰を 行うことによって定数 $a 、 k 、 n$ を求めることができ、任意の $T 、 S$ の状態における $L$ を算出できる。

\section{4. 木造住宅躯体内の温湿度計測}

\section{1 計測概要}

促進実験に先立ち、木造住宅の躯体内部の温湿度計測を行った。 対象建物は構造用集成材を用いた軸組構法であり、壁の室内側に防 湿層、室外側に通気層を有する。計測は各方位面の壁体内（断熱層 内側）において、温度、湿度を 30 分毎に記録した。建物および計測 概要を表 1 に、平面図、立面図、外壁の構成を図 2 に示す。なお、 室内は空調せず、なりゆきとした。

\section{2 計測結果}

図 $3 \cdot 4$ に各方位面の月平均温湿度変化を示す。冬季において、北 面は南面に比べて温度が低く湿度が高い傾向を示した。東西面はほ ぼ同じ推移を示し、温度約 $5 \sim 30^{\circ} \mathrm{C}$ 、湿度約 $43 \sim 67 \% \mathrm{RH}$ で推移した。 湿度は 7 月にピークを示し、最も高い南面で約 70\%RH であった。

\begin{tabular}{|c|c|c|c|}
\hline 建築地 & 茨城県つくば市 & 耐力面材 & 火山性ガラス質複層板 \\
\hline 計測期間 & $2005.11 \sim 2006.10$ & 内壁 & 石膏ボード \\
\hline 外壁 & サイディング & 屋根 & 洋瓦 \\
\hline 通気層 & あり & & \\
\hline
\end{tabular}

\section{5. 促進試験}

\section{1 実験概要}

木材の含水率はその木材が置かれた環境の温湿度によって变化する。
表 1 建物および計測概要

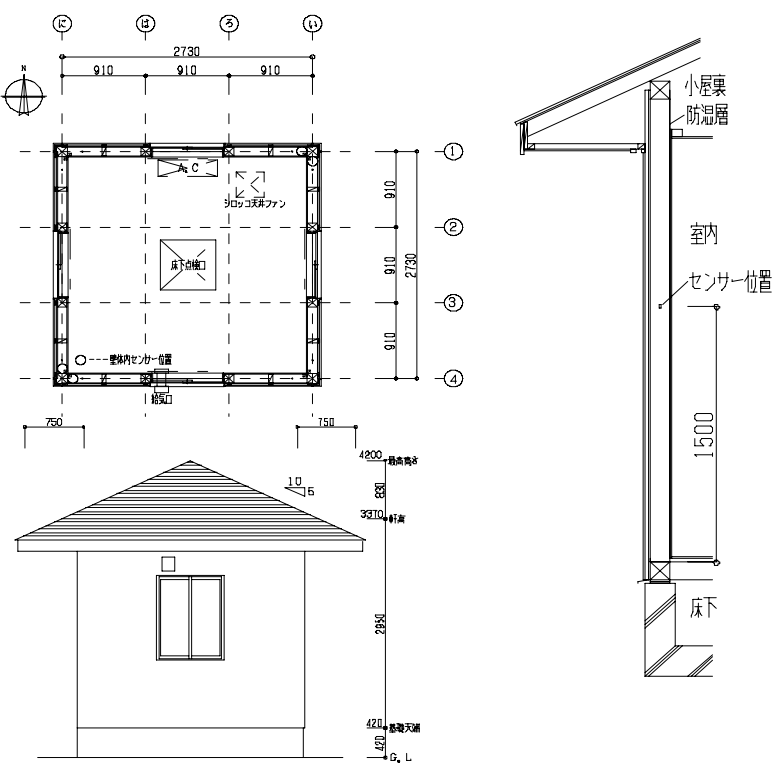

図 2 平面 $\cdot$ 立面 $\cdot$ 外壁断面図

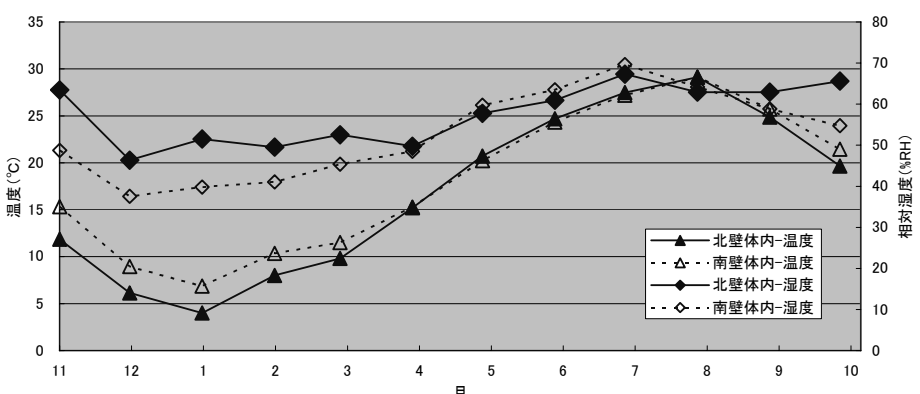

図 3 北面・南面壁体内の温湿度変化

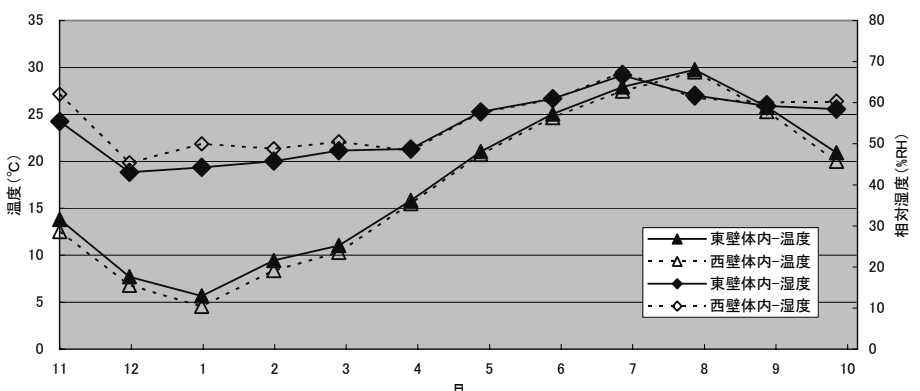

図 4 東面・西面壁体内の温湿度変化

含水率が高くなると木材の導電率が上昇する。これは鉄釘にとって 腐食電流が流れやすくなることを意味する。また、木材は温度と湿 度の影響を受け、木材中のへミセルロースのアセチル基が加水分解 することにより、酢酸を発生する。酸性環境下では鉄の腐食速度は 増加する。これらの現象を利用し、恒温恒湿器を用いて、木材に打 ち込まれた釘の発錆促進試験を行った。

図 5 に試験体図を示す。木材はスギ製材乙種 3 級とし、釘は CN65 とした。また、釷は表面処理なしのものの他、木造用金物等に使用 されている 14 種の表面処理を施したものを用いた（表 2)。木材は

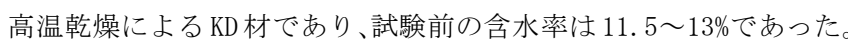
木材は木口面からの吸湿が板目面に比べて速いことが知られてい 
る。この影響を小さくするため、木口はアルミテープで被覆し、さ らに試験体ごとに各表面処理釘の配置を入れ替え、1 試験条件（温 湿度、時間）につき 4 試験体（表面処理仕様ごとに釷本数 12 本）と した。釷は促進試験終了後の引抜きを省力化するため、釷頭を木材 面より $18 \mathrm{~mm}$ 突出させた状態まで打ち込んだ。

促進試験を定めた規格では、温度条件や水準数、暴露時間などを 規定している。例えば JIS K 7226 では最低温度は終点到達時間が 5000 時間以上になるように選び、最高温度は終点到達時間が 100 時 間以上になるように選ぶとしている。また、ASTM D 4502-92 では、 加速試験温度は 5 水準とし、最低温度は実使用温度よりも $50^{\circ} \mathrm{C}$ 以上 高く設定してはならないとしている。しかしながら、現時点では木 材中の釘の劣化に関する試験条件や終点到達時間に関する知見がな く、試みの段階であるため、温湿度条件は規格にとらわれずに設定 することとした。表 3 に促進試験条件を示す。温湿度条件を 5 水準 定め、それぞれについて促進期間を 2 水準定めた。促進期間は釘突 出部の発錆状沉を随時確認しながら決定した。

\section{2 実験結果}

促進試験終了後、木材から釷を取り出し、重量、各部の径につい て計測した。錆の除去方法は JAS0 M609-912 に従い、70ㄷのクエン 酸二アンモニウム $20 \%$ 水溶液に 50 分間浸漬し、乾燥した。浸漬後に も固着している錆はワイヤブラシを用いて除去した。錆除去前後の 釘の一例を写真 1 に示す。

促進試験条件 2（70 ${ }^{\circ} \mathrm{C} 90 \% \mathrm{RH}-9 \mathrm{w} ）$ および $4\left(80^{\circ} \mathrm{C} 90 \% \mathrm{RH}-6 \mathrm{w}\right)$ では突 出部分における径の減少が木材内部における径の減少に比べて著し かった（写真 2)。促進条件 7〜10 では、釘の損傷は比較的軽微であ り、表面処理が残存しているものもあった（写真 3 )。

\section{6. 寿命予測}

\section{1 限界残存重量の設定}

耐力壁の許容耐力の低減係数は使用環境（劣化）だけでなく施工 のばらつきなどを含んだものとされていることを考慮して、本研究 では初期性能と同等の性能を確保できる最小の釘の残存重量を「限 界残存重量」とする。筆者らは過去の研究 ${ }^{7}$ で釘を発錆させた状態 での合板釘接合部のせん断実験を行い、重量残存率と許容耐力指標 との関係を確認している。これによれば、N50 釷を用いた合板耐力 壁において、釘の発錆初期は許容耐力が一旦上昇した後、重量残存 率が約 0.78 に達する点で再び初期值に戻る。

同一環境では平均腐食深さが同等になると考え、N50 釘の重量残 存率 0.78 を $\mathrm{CN} 65$ 釘に換算すると、重量残存率は約 0.82 となる。本 研究ではこれを限界残存重量とし、各種表面処理を施した釗につい ても同じ值を用いることとする。

\section{2 各促進条件における寿命の算定}

図 6 9 に、促進期間と釘の残存重量の関係の一例を促進条件ごと に示す。重量は平均値とし、表面処理仕様ごとに算出した。また、 6.1 で設定した限界残存重量に達する点、寸なわちその温湿度条件 における寿命を求め、図中に示した。一般的に、発錆による重量変 化速度は一定ではなく、発錆が進行するに従って遅くなると言われ ている ${ }^{6)}$ が、ここでは実験值の直線補完、寸なわち重量変化速度は 一定であるとした。ただし、直線補完によって算出された寿命時の 重量が 0 未満となる場合は、促進期間の短い方（条件 1、3、5、7、
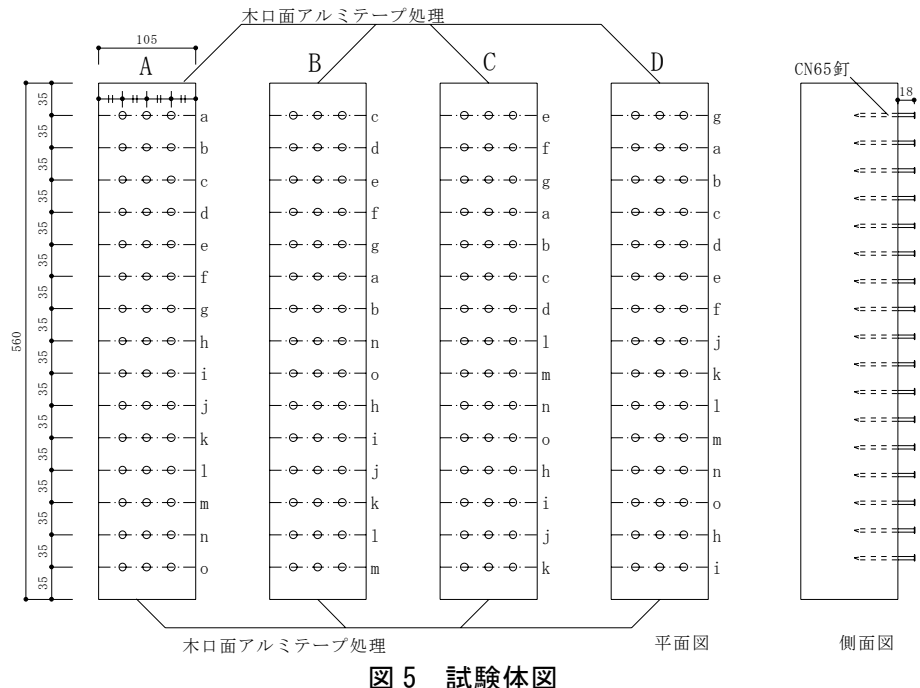

表 2 釘の表面処理仕様

\begin{tabular}{c|c||c|c||c|c}
$\mathrm{a}$ & 電気亜鉛めっき 1 & $\mathrm{f}$ & 金属系塗装 1 & $\mathrm{k}$ & 樹脂系塗装 \\
\hline $\mathrm{b}$ & 電気亜鉛めっき 2 & $\mathrm{~g}$ & 金属系塗装 2 & $\mathrm{l}$ & めっき+有機皮膜 \\
\hline $\mathrm{c}$ & 溶融亜鉛めっき & $\mathrm{h}$ & 金属・無機複合塗装 1 & $\mathrm{~m}$ & めっき+無機皮膜 \\
\hline $\mathrm{d}$ & 溶融合金めっき 1 & $\mathrm{i}$ & 金属・無機複合塗装 2 & $\mathrm{n}$ & 表面処理なし \\
\hline $\mathrm{e}$ & 溶融合金めっき 2 & $\mathrm{j}$ & 金属・樹脂複合塗装 & o & 電気亜鉛めっき 3
\end{tabular}

表 3 促進試験条件

\begin{tabular}{|c|c|c|c|}
\hline No. & 温度 $\left({ }^{\circ} \mathrm{C}\right)$ & 湿度 (\%RH) & 期間 (week) \\
\hline 1 & \multirow{2}{*}{70} & \multirow{2}{*}{90} & 4 \\
\hline 2 & & & 9 \\
\hline 3 & \multirow{2}{*}{80} & \multirow{2}{*}{90} & 3 \\
\hline 4 & & & 6 \\
\hline 5 & \multirow{2}{*}{90} & \multirow{2}{*}{90} & 1 \\
\hline 6 & & & 5 \\
\hline 7 & \multirow{2}{*}{90} & \multirow{2}{*}{80} & 4 \\
\hline 8 & & & 13 \\
\hline 9 & \multirow{2}{*}{90} & \multirow{2}{*}{70} & 9 \\
\hline 10 & & & 20 \\
\hline
\end{tabular}
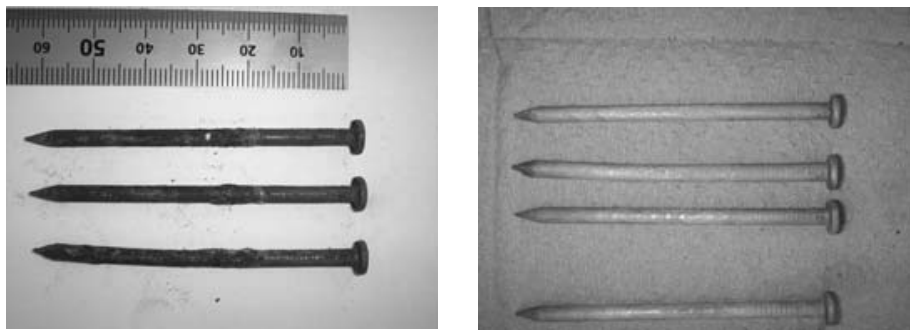

写真 1 錆除去前後の釷 $\left(90^{\circ} \mathrm{C} 90 \% \mathrm{RH}-1 \mathrm{w}\right)$

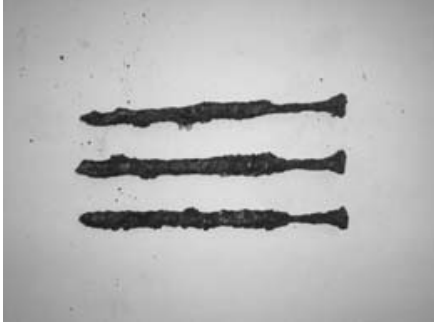

写真 2 突出部分の径が著しく 減少 $\left(70^{\circ} \mathrm{C} 90 \% \mathrm{RH}-9 \mathrm{w}\right)$

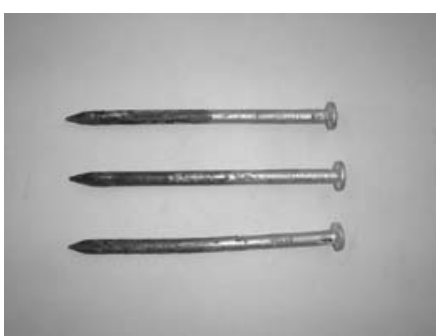

写真 3 表面処理が残存した もの $\left(90^{\circ} \mathrm{C} 70 \% \mathrm{RH}-20 \mathrm{w}\right)$ 
9）と初期状態との直線補完によって算出した。また、突出部分の径 の減少が著しかった促進条件 2 および 4 については、突出部分の径 を木材中の部分の径に換算して重量を割り増した。

\section{3 アイリングモデルの適用と諸定数の決定}

6.2 で算出された各促進条件における寿命をアイリングモデルに 適用して、諸定数を算出した。本研究では木材内の釘の発錆を対象 と寸る。湿度と平衡含水率 EMC は相関が高いが、木材内の釷への影 響は EMC の方が高いと考え、温度以外のストレス因子として EMCを 用いることとした。促進試験においては木材平衡含水率は平衡含水 率図表 ${ }^{8)}$ から読み取ることとした。各促進条件とそれぞれの条件に おける平衡含水率と寿命の一例を表 4 に示す。

$\log \mathrm{L}$ を目的変数、 $1 / \mathrm{T}$ および $\log$ (EMC) を説明変数として重回帰を 行い、得られた定数 $a 、 k 、 n$ を表 5 に示す。釘仕様 $\mathrm{j}$ および $\mathrm{k}$ につ いては、促進試験で劣化が見られず、定数の算出ができなかった。

\section{4 壁体内環境における寿命予測}

本研究では面材耐力壁の釘接合部、寸なわち柱に打ち込まれた釘 を対象として寿命予測を行う。柱の含水率は壁体内の温湿度の影響 を大きく受けると考えられるため、4.2 で得られた壁体内の温度お よび平衡含水率を用いて、壁体内環境における釷の寿命予測を行っ た。平衡含水率は下式 ${ }^{9)}$ に従って算出した。

$$
E M C=\frac{1800}{W}\left(\frac{K h}{1-K h}+\frac{K_{1} K h+2 K_{1} K_{2} K^{2} h^{2}}{1+K_{1} K h+K_{1} K_{2} K^{2} h^{2}}\right)
$$

ただし、 $E M C$ : 平衡含水率 $(\%) 、 h:$ 相対湿度 $(\% \mathrm{RH} / 100)$ 、 $W=349+1.29 T+0.0135 T^{2} 、 \quad K=0.805+0.000736 T^{-} 0.00000273 T^{2}$ 、 $K_{1}=6.27-0.00938 T^{-0} 0.000303 T^{2} 、 K_{2}=1.91+0.0407 T^{-0} 0.000298 T^{2} 、 T$ : 温度 $\left({ }^{\circ} \mathrm{C}\right)$

各月の条件における寿命 $\mathrm{L} 1$ L 12 を算出し、下式に従って寿命を 算出した。

$$
L=12 / \sum_{n=1}^{12} \frac{1}{L_{n}}
$$
表 6 寿命試算結果

\begin{tabular}{c|c}
\multicolumn{2}{c}{$\begin{array}{c}\text { 釘表面処理仕様: } \mathrm{n} \text { (処理なし) } \\
\text { 方位 }\end{array}$} \\
\hline \hline 寿命 (年) \\
\hline 北面 & 252 \\
\hline 南面 & 234 \\
\hline 東面 & 372 \\
\hline 西面 & 328
\end{tabular}

鉄釷（釷仕様 $\mathrm{n}$ : 表面処理なし）についての試算結果を表 6 に示 す。各方位壁面のうち、南面が最も撖しい条件となり、寿命は約 230 年と算出された。最も穏やかな条件である東面では約 370 年と算出 された。その他の表面処理仕様は全て約 200 年以上の值となった。

\section{7. まとめ}

木造住宅躯体内の温湿度計測、高温高湿環境による釘の促進発錆 実験とアイリングモデルを用いて、面材耐力壁における釷の寿命予 測を試みた。その結果、最も条件が厳しい南面において、鉄釷の寿 命が約 230 年と算出された。本研究では温度と EMC をパラメータと したが、厳密には温湿度と発錆酢酸濃度、経過時間と木材内酢酸の 残留率、含水率と腐食電流密度などの関係を精查して適用すべきで あり、さらに測定データを増やすことによって予測精度を向上させ ることが必要であるが、それらは今後の課題である。また、実環境 における腐食状況との比較による補正やモデルの再考等が必要と思

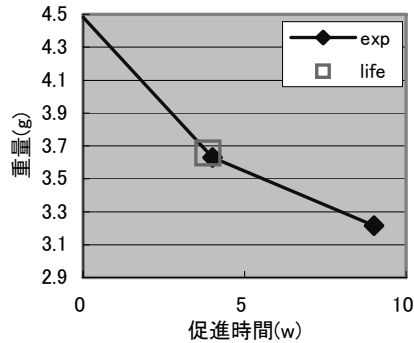

図 $6 \quad 70^{\circ} \mathrm{C} 90 \% \mathrm{RH}$

(釷表面処理仕様: $\mathrm{n}$ (処理なし)

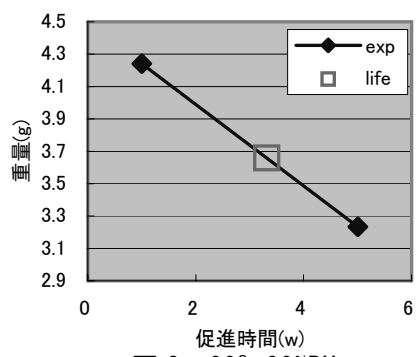

図 $8 \quad 90^{\circ} \mathrm{C} 90 \% \mathrm{RH}$

(釘表面処理仕様: $\mathrm{n}($ 処理なし) $)$

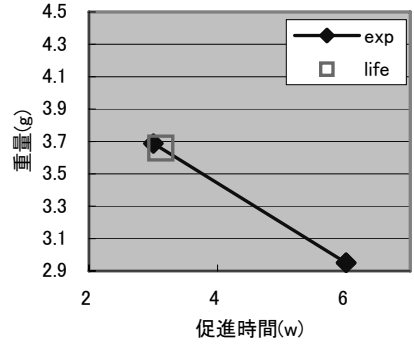

図 $780^{\circ} \mathrm{C} 90 \% \mathrm{RH}$

(釘表面処理仕様: $\mathrm{n}$ (処理なし) )

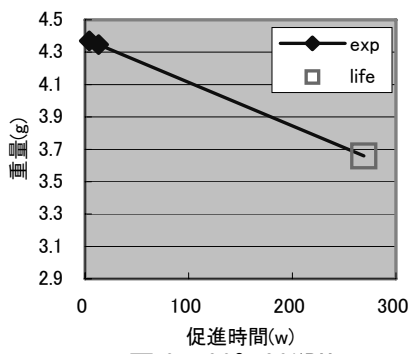

図 $990^{\circ} \mathrm{C} 80 \% \mathrm{RH}$

(釷表面処理仕様: $\mathrm{n}($ 処理なし) $)$
表 4 各促進条件における寿命（釘表面処理仕様：n（処理なし))

\begin{tabular}{r|r|r|r|r|r|r}
$\mathrm{T}\left({ }^{\circ} \mathrm{C}\right)$ & $\mathrm{RH}(\% \mathrm{RH})$ & EMC $(\%)$ & \multicolumn{1}{l}{$\mathrm{L}(\mathrm{w})$} & $1 / \mathrm{T}(1 / \mathrm{K})$ & \multicolumn{1}{l}{$\mathrm{nEMC}$} & $1 \mathrm{~nL}$ \\
\hline \hline 70 & 90 & 16.1 & 3.6 & 0.00292 & 2.779 & 1.294 \\
\hline 80 & 90 & 15.2 & 3.1 & 0.00283 & 2.721 & 1.135 \\
\hline 90 & 90 & 14.3 & 3.3 & 0.00275 & 2.660 & 1.199 \\
\hline 90 & 80 & 10.8 & 269.1 & 0.00275 & 2.380 & 5.595 \\
\hline 90 & 70 & 8.5 & 1982.9 & 0.00275 & 2.140 & 7.592
\end{tabular}

\begin{tabular}{|c|c|c|c|c|c|c|c|}
\hline & $\mathrm{a}$ & $\mathrm{k}$ & $-n$ & & $\mathrm{a}$ & $\mathrm{k}$ & $-n$ \\
\hline a & -3.1 & 15439.1 & -14.3 & i & 5.4 & 9235.7 & -11.0 \\
\hline b & 0.3 & 13362.7 & -13.4 & $\mathrm{j}$ & - & - & $\begin{array}{lll}- \\
-\end{array}$ \\
\hline c & -17.9 & 17764.6 & -11.3 & $\mathrm{k}$ & - & - & - \\
\hline $\mathrm{d}$ & -11.9 & 15978.6 & -11.6 & 1 & -2.6 & 14462.1 & -13.6 \\
\hline $\mathrm{e}$ & -4.4 & 13132.8 & -11.4 & $\mathrm{~m}$ & -12.8 & 15577.8 & -11.0 \\
\hline $\mathrm{f}$ & 4.5 & 16767.7 & -18.6 & $\mathrm{n}$ & 12.7 & 8008.4 & -12.5 \\
\hline$g$ & 0.2 & 20381.3 & -20.7 & 0 & 4. 6 & 21000.1 & -23.1 \\
\hline h & -2.9 & 16010.4 & -15.1 & & & & \\
\hline
\end{tabular}

表 5 各釘表面処理仕様ごとの諸定数

われる。現時点では、躯体に乾燥材を用い、防湿層や壁体内通気を 確保するなど木材の含水率が上昇しないように対策した上で、釘に 何らかの表面処理を施せば、十分な耐久性を有するといえよう。

\section{参考文献}

1）堤洋樹、小松幸夫 : 1980 年以降における木造専用住宅の寿命の推移, 日本 建築学会計画系論文集, 第 580 号, pp. 169-174, 2004. 6

2）神山幸弘ほか: 木造住宅構造部材の耐久性向上技術に関する研究, 日本建 築学会大会学術講演梗概集（北海道），構造 II , pp. 1283-1284, 1986.8

3）早川淨：高分子材料の寿命評価・予測法, アイピーシー, 1994.5

4) ASTM D 3045-92:Standard practice for heat aging of plastics without load (Reapproved 2003)

5）今村博之ほか：木材利用の科学,共立出版, 1983.3

6）腐食防食協会：腐食防食ハンドブック,丸善, 2004.12

7）石山央樹、腰原幹雄：釷接合部の劣化時せん断性能に関する実験的研究, 日本建築学会構造系論文集, 第 646 号, pp. 2281-2289, 2009. 12

8）森林総合研究所 : 木材工業ハンドブック, 丸善, 2004.3

9) Simpson, W. T. :Predicting equilibrium moisture content of wood by mathematical mode1s, Wood and Fiber, 5(1), pp41-49, 1973

[2009 年 10 月 19 日原稿受理 2010 年 1 月 8 日採用決定 $]$ 